\title{
La fábrica de azúcar El Tarajal (Málaga), obra del arquitecto Manuel Rivera Vera
}

\author{
El Tarajal Sugar Factory (Malaga), Work of the Architect Manuel Rivera Vera
}

\author{
Francisco José Rodríguez Marín \\ Universidad de Málaga \\ Departamento de Historia del Arte \\ https://orcid.org/0000-0002-6613-1148 \\ fjrodriguez@uma.es
}

Recibido: 05/07/2021; Revisado: 20/12/2021; Aceptado: 29/12/2021

\begin{abstract}
Resumen
Tras el declive del esplendoroso desarrollo industrial experimentado por Málaga a finales del siglo XIX, se dio paso a una recuperación parcial durante el primer tercio del siglo xx. Entre las empresas industriales de nueva creación se hallaban las fábricas de azúcar adaptadas tanto a la transformación de la caña como de remolacha. Una de ellas fue El Tarajal, promovida por destacados miembros de la oligarquía empresarial y política de la ciudad. El edificio es el más monumental y mejor conservado de la ciudad, cuya autoría ha podido documentarse ahora en la persona del arquitecto Manuel Rivera Vera.
\end{abstract}

Palabras clave: Málaga, arquitectura industrial, fábrica de azúcar, Rivera Vera.

\begin{abstract}
After the petering out of the splendid industrial boom in Malaga at the end of the 19th century, the city experienced a partial recovery during the first third of the 20th century. Among the newly-created industrial enterprises were the sugar factories adapted to the processing of both cane and beet. One of them was El Tarajal, promoted by prominent members of the city's business and political oligarchy. The building is the most monumental and best preserved in the city, whose creation has now been accredited to the architect Manuel Rivera Vera.
\end{abstract}

Keywords: Malaga, Industrial Architecture, Sugar Factory, Rivera Vera. 


\section{INTRODUCCIÓN}

El patrimonio industrial es una de las categorías patrimoniales introducida durante las últimas décadas en el ámbito del patrimonio cultural, y puede ser material o inmaterial. Hacia la mediación del siglo xIX Málaga experimentó un importantísimo y poco conocido desarrollo industrial que la situó prácticamente a la cabeza frente a otras ciudades del país (SANTIAGO, BONILLA y GUZMÁN, 2001: 2532). Aunque diversos factores desencadenaron una notable crisis económica en la provincia -la epidemia de filoxera fue el más notable-, los años centrales de la segunda década del siglo xx fueron de recuperación, constatándose la creación de nuevas empresas de base industrial, como la metalúrgica Los guindos, la fábrica de abonos La Trinidad, la de cementos Goliat, o las azucareras Hispania y el Tarajal (GARCía Montoro y PARejo BARRANCO, 1986: 66). Diversas circunstancias coyunturales y estructurales ocasionaron que la mayor parte de estas empresas desaparecieran posteriormente, y el nuevo ciclo económico, a partir de mediados del siglo $x x$, orientado hacia el turismo, ocasionó la pérdida del importante patrimonio industrial que se había generado. La nueva legislación del patrimonio y la sensibilidad que la sociedad ha generado hacia los valores subyacentes en esta modalidad de patrimonio han sustentado un progresivo sentimiento de aprecio hacia los elementos que se interpretan como testimonio material del periodo del desarrollo industrial de la ciudad.

Uno de los sectores industriales en los que destacó Málaga fue el de la transformación de la caña de azúcar, cuyo punto de arranque estuvo en 1860 con la fábrica de refino de azúcar promovida por Martín Heredia, a la que a partir de 1863 siguieron otras promovidas por destacados miembros de la burguesía local, como Larios, Huelin, Castel y Briales (Pezzi CristóBAL, 2019: 140). Hacia finales del siglo XIX el azúcar de caña se enfrentó a la dura competencia de la remolacha azucarera, y entre 1910 y 1914 supuso tan solo el 11,7\% del total de la producción. La creación de la Sociedad General Azucarera fue una iniciativa empresarial que trató de afrontar la nueva situación, pero incluso la sobreproducción de azúcar de remolacha provocó una bajada de precios que perjudicó a ambas modalidades (GUZMÁN, SANTIAGO y BONILLA, 2005: 79).

Otra de las acciones empresariales para superar la crisis del sector fue la creación de nuevas fábricas, adaptadas al doble proceso de transformación, de caña y remolacha. Entre ellas se encuentra la Azucarera Malagueña El Tarajal -también denominada de Ntra. Sra. de la Victoria-, que fue promovida por destacados miembros de la élite empresarial y política de la ciudad. El edificio industrial, por su gran porte, calidad arquitectónica y destacado volumen emergente en medio de la campiña, ha llamado siempre poderosamente la atención de los ciudadanos que circulan por las nuevas carreteras que se han abierto en su derredor. El edificio, sin embargo, permanece en estado de abandono y ha venido siendo objeto de diversas reivindicaciones que permitan su recuperación.

\subsection{Objetivos}

Como contribución y apoyo a esta reivindicación se plantea esta investigación, que en primer lugar se propone estudiar el contexto social, económico y tecnológico en el que surgió esta nueva empresa. Otro de los objetivos ha sido el de lograr 
sacar del anonimato a un edificio patrimonial destacado de la ciudad de Málaga, logrando confirmar la autoría del arquitecto Manuel Rivera Vera.

\subsection{Metodología}

Para ello se ha recurrido a fuentes poco usuales en la investigación histórica, como son las escrituras aún custodiadas en el archivo notarial -que no es público-, la inscripción en el registro de la propiedad, además de las actas capitulares del ayuntamiento de Málaga y la literatura científica especializada sobre el tema. Las últimas reflexiones se dedican a analizar la condición actual del edificio, su situación patrimonial y las posibilidades que ofrece de cara a acoger nuevos usos tras una necesaria rehabilitación.

\section{BREVE HISTORIA DE LA CAÑA DE AZÚCAR EN MÁLAGA Y GRANADA}

Especificar la localización geográfica del cultivo de la caña de azúcar en la península ibérica podría considerarse casi una redundancia innecesaria: las exigencias climáticas de esta planta subtropical, traída y adaptada por los musulmanes, solo puede darse en el sur peninsular ${ }^{1}$ y junto al litoral costero, donde se garantiza la ausencia de heladas, y siempre que se disponga de sistemas de regadío, ya que a diferencia de su zona de origen, en la península el periodo de crecimiento de la planta coincide con ausencia de lluvias (PIÑAR y GIMÉNEZ, 1998: 170-172). Esta gramínea llegó a la península a finales del siglo IX, se aclimató y posteriormente pasó a las Islas Canarias y las Azores, hasta que Cristóbal Colón la llevó a América en su segundo viaje, en 1494 (CAMARERO y CAMPOS, 1993: 246).

Los sistemas de producción iniciales, en trapiches movidos por fuerza de sangre o primitivos ingenios hidráulicos, pueden calificarse casi de artesanales. La mejor adaptación a tierras americanas, donde la producción y la calidad eran mayores, tampoco ayudó a mejorar el proceso en la península. El panorama cambió cuando en 1844 Ramón de la Sagra introdujo el sistema industrial Derosne, basado en el uso del vapor, que ya llevaba tiempo implantado en otros países con grandes resultados en cuanto a mejora de la calidad y la productividad. Aunque De la Sagra personalmente fracasó en su propósito por una serie de avatares que lo arruinaron (CAMBRón, 1999: 39-41), la industria azucarera de caña, al modernizarse, adoptó un rumbo inesperado de crecimiento, pues las inversiones garantizaban una alta rentabilidad y un abaratamiento de costes, provocando que de producto de lujo, el azúcar pasase a convertirse en un consumo habitual, comportamiento reforzado por la generalización de demanda de coloniales como el café y el cacao. Algunas familias industriales constituyeron una oligarquía azucarera que acaparó casi la totalidad del sector, como es el caso de familias afincadas en Málaga, como Larios y Heredia, y los Agrela en Granada (PIÑAR y GiMÉNEZ, 1998: 175).

El cultivo y transformación posterior de la caña de azúcar mantuvo un ritmo

1 En los momentos de mayor expansión el cultivo de la caña de azúcar se extendió hasta zonas del Levante español y los puntos más orientales del litoral gaditano, además de las islas canarias, de donde prácticamente desapareció por el agotamiento de la madera, combustible utilizado durante el periodo preindustrial 
creciente hasta finales del siglo XIX, resultando afectado el sector por una serie de factores adversos -varias heladas concatenadas- o la incipiente competencia del azúcar de remolacha, cuyo cultivo, a diferencia de la caña, no era exigente en cuanto a suelos y clima y copó el aumento de la demanda ocasionado por la pérdida de Cuba. El declive iniciado se detuvo hacia la década de los años veinte del nuevo siglo, y el número de ingenios azucareros alcanzó un momento máximo de expansión en 1936, contabilizándose 36 distribuidos entre Málaga y Granada. Tras este punto álgido se inició un nuevo proceso de retroceso, caracterizado por la concentración industrial y el cierre de las fábricas menos rentables para continuar compitiendo con las restantes, mientras que la presencia del azúcar de remolacha casi se generalizaba en el mercado. En 1940 aún estaban activas 11 fábricas de caña entre Málaga, Granada y una de ellas en Adra, Almería (GuZMÁN, SANTIAGO y BoniLla, 2005: 79).

La última fábrica azucarera de Málaga capital (Hispania) cerró en 1994, y la última granadina, la de Salobreña, lo hizo en 2007 (RodRíGUEZ, 2009). En la actualidad el azúcar de caña constituye una especialidad demandada únicamente por el sector de la dietética, satisfaciendo la demanda mediante la importación, aunque se mantienen en Málaga y Granada algunos cultivos de caña residuales más relacionados con su uso en cócteles y el ocio que con los hábitos alimentarios.

\section{LA CAÑA DE AZÚCAR EN MÁLAGA EN LA SEGUNDA DÉCADA DEL SIGLO XX}

Las vicisitudes de la industria azucarera se hallaban en estrecha relación con las variedades cultivadas. Hacia la década de los años sesenta del siglo XIX las variedades predominantes en la Axarquía malagueña eran la algarrobeña y la doradilla, comenzando su expansión una variedad americana, la sacharum violácea, que se asentó, sobre todo, en Málaga y la costa occidental, en San Pedro Alcántara. El objetivo era, obviamente, asentar especies más productivas. Pero nuevos problemas se sumaron en el delicado momento de finales del siglo XIX, con la plaga del mosaico, que secaba las hojas de la planta y acababa debilitándola, disminuyendo drásticamente su rendimiento en guarapo o jugo de caña.

El gobierno, consciente del papel que los cultivos industriales desempeñaban como base del desarrollo industrial, apostó por la creación de instituciones específicamente destinadas a la investigación agrícola. Las denominadas estaciones de agricultura trabajaban en la aclimatación de nuevos cultivos y frutos comestibles, pero también en la adaptación de especies más rentables y resistentes a las plagas. Desde comienzos del siglo xx en Málaga se establecieron dos de estos centros (Churriana y Torrox) y un tercero en Motril (Granada). Precisamente en éste último su director, el ingeniero agrícola Arsenio Rueda, obtuvo dos importantes éxitos: localizar el origen de la plaga del mosaico -transmitida por el pulgón del maíz, empleado, por ignorancia, en la delimitación de parcelas-, e identificar la especie de caña más resistente a la plaga: la Java 36. También fue logro de Rueda conseguir que la planta floreciese, por primera vez en la península, gracias al cultivo en invernadero (LópEz LUENGO, 2004).

En el centro de Torrox se experimentó con 21 especies procedentes de diversas partes del mundo, y una de ellas, la Poj Java $n^{\circ}$. 2715, fue seleccionada, por su mayor rendimiento, para la repoblación de la vega (RODRÍGUEZ, 2012). 
Otra acción expresiva de la importancia que en estos años se daba a la modernización de la agricultura fue la construcción de los embalses de El Chorro (1914-1921) y Gaitanes (1924-1927). Aunque entre sus objetivos se hallaba la regularización de los ríos Guadalhorce y Guadalteba para evitar inundaciones, así como la producción de electricidad, no menos importante fue la conversión de terrenos agrícolas de secano en regadío (BROTONS, 1999: 79). Muy elocuente fue el hecho de que se aprovechó la visita del rey Alfonso XIII para inaugurar el primero de los pantanos, en mayo de 1921, para la puesta de la primera piedra de los nuevos canales de riego proyectados, cuya puesta en funcionamiento llevaría un plazo de 4 ó 5 años. Para la firma protocolaria del acta por el rey se preparó una mesa y un asiento confeccionados íntegramente con cañas de azúcar, elocuente metáfora del impulso que se pretendía dar a esta planta industrial gracias a las nuevas posibilidades de regadío en terrenos antes de secano (AlFARO, 1921: 6-36). Es evidente que, en este momento, se miraba a esta planta como una fuente de riqueza relacionada con el progreso de la economía y la sociedad. Incluso episodios tan trágicos como la Primera Guerra Mundial tuvo un efecto positivo para la economía de países no beligerantes, como España, que entre otros productos exportó considerables cantidades de miel de caña ${ }^{2}$ por sus excelentes cualidades nutritivas, facilidad de transporte y fácil conservación, revelándolo como un complemento alimenticio muy adecuado para las tropas combatientes.

Es evidente la correlación entre todos estos acontecimientos para configurar un panorama optimista y halagüeño para nuevas apuestas empresariales, pues se ignoraba entonces la magnitud que llegaría a alcanzar la gran crisis económica de finales de 1929 y las consecuencias detractoras para el desarrollo para todos los países, España incluido. Se constituyeron nuevas empresas basadas en el cultivo y transformación de la caña de azúcar. La que tras algunos cambios de denominación acabo llamándose Azucarera Hispania -a la que dedicaremos un próximo trabajo- se constituyó el 12 de mayo de 1930, apenas un mes antes que la que nos ocupa en este trabajo. Hispania se ubicó en un emplazamiento estratégico: junto a la carretera de Cádiz -importante vía de comunicación para el transportey cercana a la desembocadura del río Guadalhorce, cuyas aguas regaron una extensísima superficie de marjales con caña de azúcar, lo que supondría una competencia directa para la fábrica de El Tarajal (RodRíGUEZ, 2009).

\section{ALTA SOCIEDAD PARA UNA SOCIEDAD MERCANTIL: EL TARAJAL}

La fórmula empresarial elegida para este nuevo proyecto industrial fue la de Sociedad Anónima, en la que cada integrante adquirió un determinado número de acciones con valor de 500 pesetas cada una, hasta reunir el capital necesario para sufragar el costo de construcción de la nueva fábrica y su maquinaria, aunque se pretendía ampliar el negocio en el futuro con nuevas fábricas azucareras.

Los integrantes de la empresa provenían de la alta sociedad malagueña, ya familiarizados con el mundo de la política y los negocios. Un claro ejemplo lo constituye la composición del consejo de administración. La presidencia de la

2 Producto obtenido mediante la concentración y tratamiento del guarapo, al que en el proceso de cocción se añade un ácido que descompone la glucosa en fructosa y sacarosa, impidiendo la fermentación. Llevado hasta el grado de densidad deseado, se caracteriza por la conservación de sus propiedades nutritivas, ser muy energético y larga durabilidad 
sociedad la detentó Manuel Romero Raggio, quien había sido alcalde de Málaga entre 1918 y 1920 y diputado a Cortes en 1923. ${ }^{3}$ Militó en Izquierda Liberal, pero esto no le impidió en 1925 ser representante en España de Haynes Company, distribuidora de los automóviles Chrysler. Como profesión declaraba ser corredor de comercio. Murió en 1937 represaliado por el bando republicano. ${ }^{4}$

Del vicepresidente de la sociedad, Pedro Valls y Chacón, sabemos que adquirió el segundo coche que llegó a Málaga -matriculado en 1911-, ${ }^{5}$ dato que debemos interpretarse en clave de prestigio social. El secretario del consejo fue Agustín Cabeza de Vaca y Ruiz-Soldado, xv marqués de Crópani, quien había contraído matrimonio con una hermana de Pedro Valls, María Teresa, ${ }^{6}$ dando idea del estrecho vínculo establecido entre los socios.

Otro de los vocales, Salvador Hinojosa Carvajal, era propietario de numerosas tierras en Campillos. Fue padre del poeta de la generación del 27 José María Hinojosa. Ambos fueron represaliados al inicio de la guerra civil por sus posiciones conservadoras (PÉREZ, 2017). También perdió la vida en las mismas circunstancias quien fue vocal de la sociedad José Pérez del Pulgar y Campos, hijo del conde de las Infantas, abogado y propietario, y casado con $\mathrm{M}^{\mathrm{a}}$. del Pilar Valls, hermana del vicepresidente Pedro Valls. ${ }^{7}$ José López de Carvajal, abogado y único soltero del consejo de administración, fue vicesecretario.

Otro de los vocales, Antonio Gil de Sola -de profesión ingeniero-, se casó con Concepción Nagel Álvarez-Net, ${ }^{8}$ perteneciente a una destacada y acaudalada familia de comerciantes. El último de los vocales, Rogelio Oliva Prolongo, fue propietario agrícola, y su matrimonio con Aurora Tejón tuvo lugar en la capilla del Palacio Episcopal, ${ }^{9}$ posibilidad restringida a una reducida esfera de la sociedad malagueña. Su familia, originaria de la localidad de Cártama, fue la fundadora de una conocida empresa de productos cárnicos, Prolongo, famosa por crear un embutido al estilo italiano que ha acabado por convertirse en un estilo de salchichón conocido como de «Málaga».

\section{SOCIEDAD ANÓNIMA «AZUCARERA EL TARAJAL»}

Ya con los Estatutos por los que se había de regir la sociedad redactados, todos los miembros del consejo de administración y sus respectivas esposas comparecieron ante el notario Francisco López Cózar -sustituto de Francisco Díaz

\footnotetext{
3https://www.congreso.es/historico-diputados?p_p_id=historicodiputados\&p_p_lifecycle=0\&p_p_ state $=$ normal\&p_p_mode $=$ view\&_historicodiputados_mvcRenderCommandName $=$ mostrarDetal le\&_historicodiputados_nume $=52258$ (recuperado el 3 de julio de 2021).

$4 \mathrm{http}: / /$ diccionario.sensagent.com/Manuel\%20Romero\%20Raggio/es-es/ (recuperado el 3 de julio de 2021).

5 Muñoz Antivón, J.F., Historia del automóvil en Málaga, https:/ / historiadelautomovilenmalaga.blogspot.com/2018/11/blog-post.html (recuperado el 3 de julio de 2021).

6 https://gw.geneanet.org/lmvillena?lang=es\&n=agustin+cabeza + de $+v a c a+y+$ ruiz + soldado\&oc $=0$ $\& p=x$ (recuperado el 3 de julio de 2021).

7 https://gw.geneanet.org/flofer28?lang=en\&pz=fernando\&nz=alarcon+porras\&ocz=0\&p=jose\&n= perez+del+pulgar+y+campos (recuperado el 3 de julio de 2021).

8 https://gw.geneanet.org/flofer28?lang=es\&n=gil+de+sola\&oc=0\&p=antonio (recuperado el 3 de julio de 2021).

9 https://gw.geneanet.org/flofer28?lang=en\&n=oliva+prolongo\&oc $=0 \& p=$ rogelio (recuperado el 3 de julio de 2021).
} 
Trevilla- el 13 de junio de 1930. En la escritura de constitución de la sociedad mercantil se adoptaron algunos acuerdos, como que la sede provisional de la sociedad quedaría establecida en los bajos del edificio de calle Âlamos -entonces denominada Cánovas del Castillo- no. 7 de la ciudad. Este edificio -que se conserva- es el actualmente denominado Palacete del Marqués de Crópani, pues quien asumió la función de secretario de la sociedad la hizo residir en su propio domicilio.

Otro importante acuerdo consistió en que los hermanos Pedro, ${ }^{10}$ Josefa, María del Pilar y Teresa Valls Chacón, suscribían cada uno de ellos 40 acciones, equivalentes a 20.000 pesetas. Sin embargo esta familia aportaba a la sociedad un haza de secano denominada La Viña, segregada de la hacienda El Tarajal -mucho más amplia-, la cual fue valorada en 80.000 pesetas, con lo que se vieron eximidos de entregar cantidad monetaria alguna. Esta hacienda la habían recibido en herencia de sus padres. La hacienda El Tarajal sí que era parcialmente de regadío a través de la acequia de Labradores, mientras que otra parte se regaba con la ayuda de máquinas de vapor para extraer el agua de pozos, y el resto de la superficie, era de secano, anteriormente dedicada a viñedo -perdidos por la filoxera- y se ocupaba en este momento con arbolado y otros cultivos. Conservaba también varios edificios, dos albercas, tres pozos y otras tantas máquinas de vapor, dos fijas y otra locomóvil. Uno de los inmuebles aún se utilizaba como bodega.

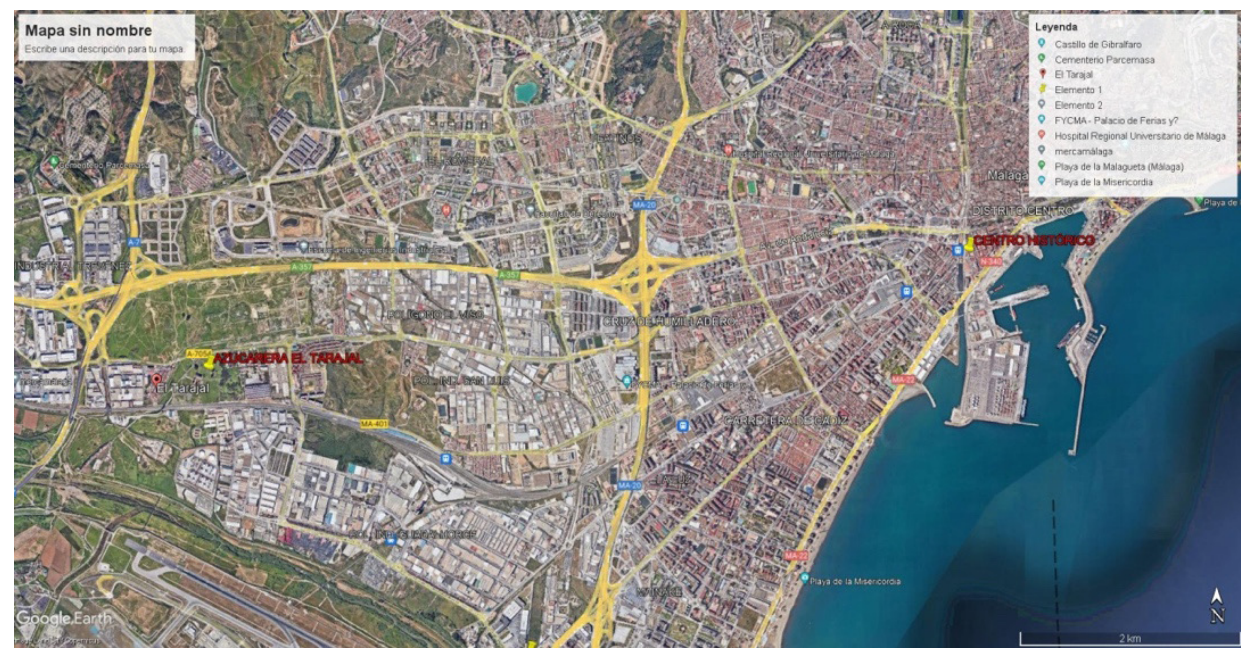

Figura 1. Emplazamiento de la fábrica en relación al resto de la ciudad. Fuente: Google Earth.

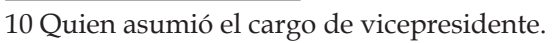




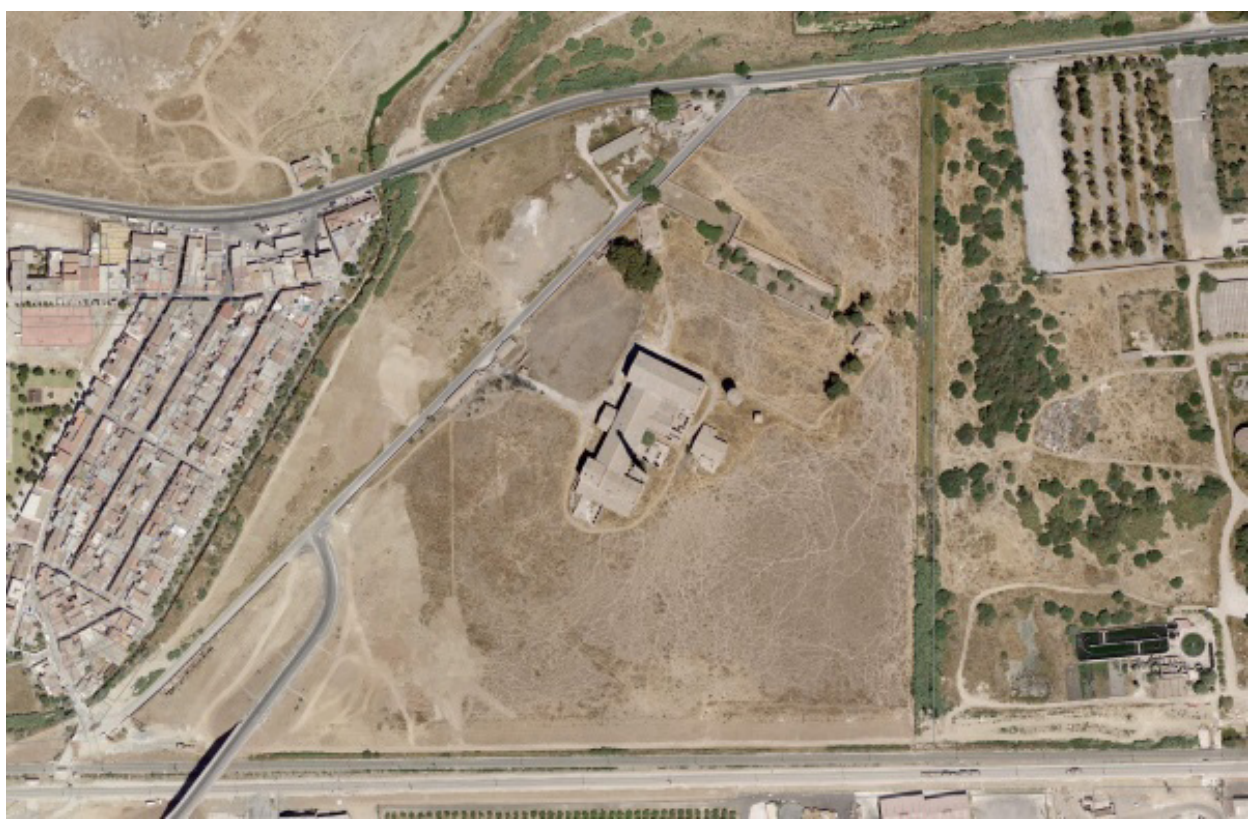

Figura 2. Parcela de El Tarajal. Vista aérea. Fuente: Google Earth.

Una vez segregada la parcela entregada a la sociedad mercantil, los señores Valls quedaron como propietarios del resto de la finca, que medía algo más de 125 has. La única limitación que aceptaron a su pleno dominio fue una servidumbre de paso de agua subterránea, tomada desde el río Guadalhorce y conducida y canalizada mediante una tubería de un metro de diámetro hasta la parcela sobre la que se había de construir la fábrica, dispuesta a una profundidad suficiente como para no perjudicar la actividad agrícola. Una cláusula de la escritura establecía que si se extinguiese la sociedad mercantil o no llegase a construirse la fábrica, la servidumbre quedaría igualmente extinta.

La escritura original inserta la copia mecanografiada de los Estatutos, incluyendo la composición del consejo de administración presidido por Manuel Romero Raggio y la vicepresidencia de Pedro Valls Chacón. ${ }^{11}$ La citada normativa recogía los fines de la sociedad en sentido amplio, de forma que en un futuro no supusiese ninguna cortapisa a ampliaciones o nuevas operaciones. Así se establecía como fin primero la construcción de una o varias fábricas de azúcar en la vega de Málaga dedicadas a la fabricación de azúcar de remolacha o caña, así como otras operaciones mercantiles, agrícolas e industriales.

El capital social quedó fijado en 5.000 .000 de pesetas divididos en 10.000 acciones de 500 pesetas cada una, admitiendo el pago de las mismas en fincas o edificaciones rústicas necesarias para la construcción de la fábrica. Otra estrategia

11 Escritura de constitución de la Sociedad Anónima Azucarera malagueña El Tarajal, 13 de junio de 1930. Agradezco al notario archivero de Málaga, D. Juan Enrique García Jiménez, las facilidades otorgadas para la consulta de este documento, que aún no ha sido transferido al Archivo Histórico Provincial y carece, por tanto, de signatura 
encaminada a procurar el éxito del negocio consistió en reservar 1 millón de pesetas en acciones para los agricultores de la vega, con el privilegio de recibir un dividendo del 3\%, comprometiéndose a cambio a entregar anualmente a la fábrica 10.000 kgs. de remolacha o caña de azúcar de las variedades admitidas por la sociedad durante un periodo de 12 años, transcurrido el cual cesaría este privilegio. Con esta fórmula se perseguía garantizar que a la fábrica no le faltase materia prima, y que al combinar caña con remolacha no resultase afectada por la estacionalidad implícita al uso exclusivo de caña, que obligaba al cierre temporal de otras fábricas.

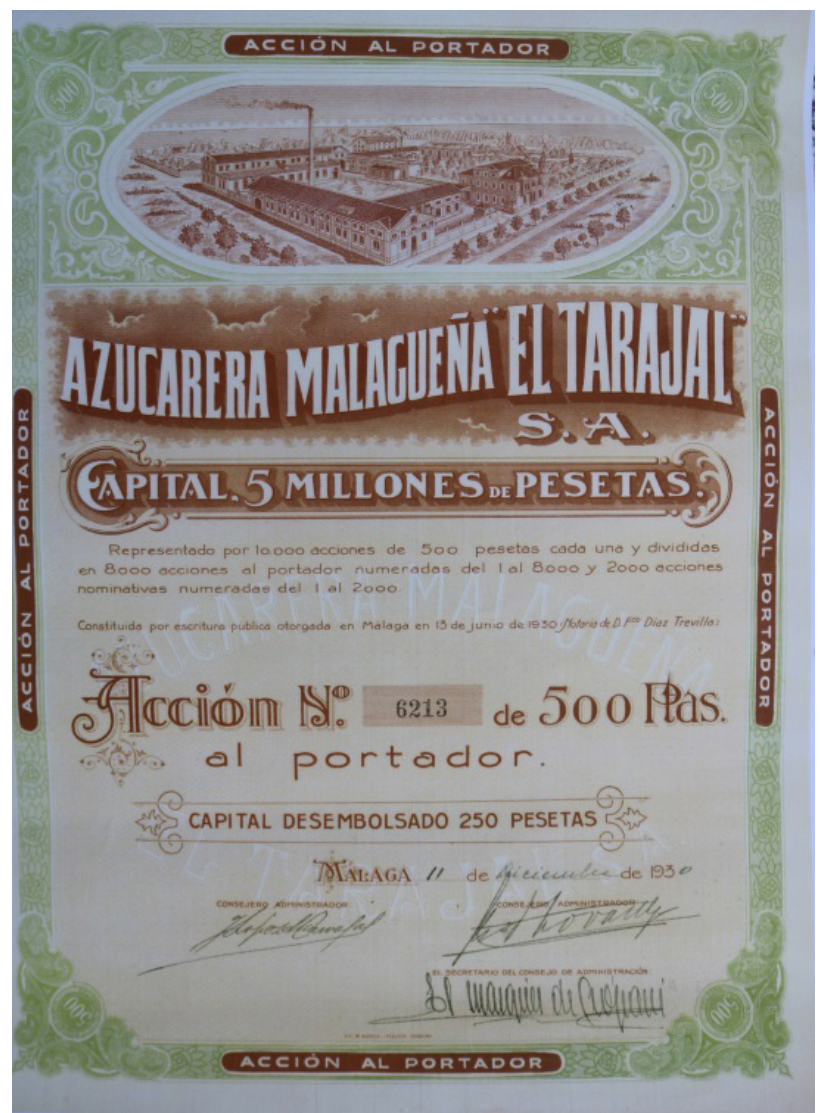

Figura 3. Acción de la empresa El Tarajal. Fuente: Colección Miguel Giménez Yanguas.

\section{MANUEL RIVERA VERA, ARQUITECTO}

Manuel Rivera Vera nació en Málaga en 1879, en la calle Nuño Gómez. Fue hijo del también arquitecto Manuel Rivera Valentín, y estilísticamente pertenece también a una generación posterior. De las tres etapas en las que Navascués 
Palacio divide el periodo de la arquitectura decimonónica ${ }^{12}$ (NAvASCUES, 1973: 171), Rivera Vera pertenece a la tercera.

Estudió en la Escuela de Arquitectura de Madrid, donde concluyó sus estudios en 1903. Al año siguiente ya estaba ejerciendo la profesión en Málaga, protagonizando los ejemplos más tempranos de introducción del estilo modernista en la ciudad. Aunque es autor de edificios claramente clasificables en este estilo, tanto en la versión de modernismo vienés (como Villa Suecia) como de modernismo curvilíneo o mediterráneo (Almacenes Félix Sáenz), no puede calificársele de arquitecto modernista, siendo su opción más habitual el eclecticismo con influencia modernista.

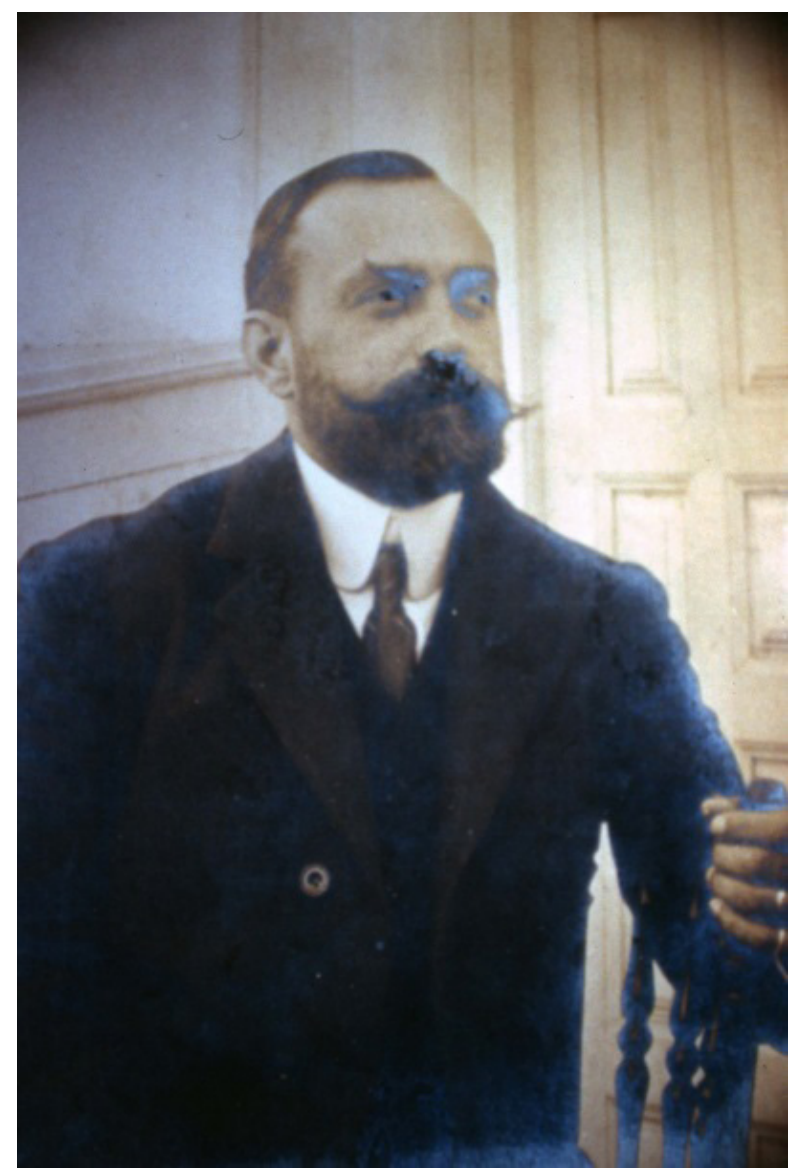

Figura 4. Manuel Rivera Vera. Fuente: Archivo Arenas.

\footnotetext{
12 Vienen a coincidir con el periodo Fernandino (imposición del academicismo clasicista), el Isabelino (liberalismo también en la arquitectura) y el de la restauración borbónica, en el que considera que se recupera el nivel de la arquitectura conectándola con la arquitectura europea. En este tercer periodo clasifica, por ejemplo, a Gaudí (NAVASCUES y QUESADA, 1992: 14)
} 
Tras un periodo de desempeño del cargo de arquitecto municipal de forma interina, fue nombrado arquitecto municipal titular en 1909, alternando esta función con el ejercicio privado de la profesión. En su desempeño profesional tocó casi todas las tipologías arquitectónicas: arquitectura funeraria, doméstica, pública, del ocio (cines Echegaray y Goya), instituciones de beneficencia, arquitectura pública y arquitectura industrial. Su obra más reconocida y afamada es el edificio consistorial de Málaga, proyecto firmado conjuntamente con el también arquitecto Fernando Guerrero Strachan, con quien le unía una relación de amistad y con quien colaboró en no pocas ocasiones.

Dentro de la parcela de la arquitectura industrial redactó los proyectos para la construcción de un pabellón en la fábrica del Gas de Málaga (1913), un almacén con oficinas en calle Calvo (1913), Talleres y Oficinas para la Sociedad Pesquera Malagueña (1913), almacenes en calle Cauce (1914), pabellón para la fábrica de aceites Gaillard (Aceitera Malagueña, Huelin, 1918), pabellón para la Cooperativa de Altos Hornos de Málaga (Sociedad Metalúrgica y Minera de Málaga, 1918) y Fábrica de Aserrar Maderas de Taillefer (1920).

En 1922 Rivera Vera ya no ejercía como arquitecto municipal, pero pertenecía a la corporación municipal como concejal reformista. Su dedicación a la política la compaginó con el ejercicio privado de la profesión, ya que conocemos algunos proyectos de su autoría con fecha posterior a este año. Sin embargo, la ausencia de clasificación exhaustiva de la documentación posterior a esta fecha en el archivo municipal de la ciudad nos ha privado de conocer el rumbo profesional de este arquitecto en las dos últimas décadas de su vida. Falleció en 1940. Su prestigio y reconocimiento eran estimables, ya que cuando se produjo el trágico incendio de la Aduana en 1922 fue consultada su opinión técnica (RODRíGUEZ, 1992-1993: 135248).

Fuentes orales de los descendientes sumaban a su obra una fábrica de azúcar, ${ }^{13}$ sin que hasta el momento presente hubiese podido confirmarse documentalmente esta afirmación ni mucho menos concretar de cual se trataba.

\section{AVATARES DEL PROYECTO DE LA AZUCARERA EL TARAJAL}

Los ya mencionados Estatutos de la Sociedad Mercantil Azucarera Malagueña El Tarajal recogen la intención de construir una primera fábrica -que a la larga sería la única- en la vega de Málaga, en los terrenos disponibles cercanos al río Guadalhorce. Este edificio industrial, notable por la nobleza y monumentalidad de su arquitectura, así como por su relativo buen estado de conservación, ha permanecido hasta el momento como obra anónima, hasta que la documentación ha logrado confirmar la autoría de Rivera Vera. Esta aportación inédita se confirma con algunos rasgos estilísticos de la fábrica, observables en otras obras de la producción del arquitecto.

Hay otro aspecto de confirmación inferida, y es el hecho de que el presidente de la sociedad mercantil, Manuel Romero Raggio, era alcalde de la ciudad en el momento en el que se inauguró el palacio consistorial de Málaga en 1919. Cuando llegó el momento de encargar el proyecto de la fábrica de azúcar, el prestigioso

13 Información aportada por $\mathrm{D}^{\mathrm{a}}$. Adelaida Rivera López, descendiente del arquitecto Rivera Vera. 
arquitecto Fernando Guerrero Strachan ya había fallecido, el 3 de abril de 1930 . Nada tiene de extrañar que el presidente de la sociedad mercantil recurriese a la seguridad de un arquitecto conocido y reconocido, como fue Manuel Rivera Vera, coautor, junto a Strachan, del palacio consistorial.

Como ya indicamos, el proyecto constructivo de la fábrica aún no ha aparecido $^{14}$, pero si contamos con una irrefutable prueba documental en las actas capitulares del año en el que las obras se hallaban ya iniciadas:

Diose cuenta del expediente instruido con motivo de las obras de nueva planta que se vienen efectuando en terrenos de la finca denominada «El Tarajal» para la construcción de una fábrica, en el que aparece un informe del arquitecto municipal manifestando que los planos presentados por Don Manuel Rivera comprende la totalidad de las obras o edificios en construcción en la totalidad, presentándose además los planos de los edificios destinados a Estación y viviendas, la cual no ha sido empezada, acompañando una nueva liquidación importando 725,50 pesetas que corresponde al total de las obras que figuran en los citados planos y la cerca de los terrenos haciendo constar que no ha podido hacer la medición definitiva por no encontrarse en la obra todos los planos ni estar los edificios terminados y que la penalidad que a dichas obras corresponde según la Ordenanza artículo 19 es la de 2176,50 ptas... ${ }^{15}$

El documento continua recogiendo los pareceres de diversos concejales, concluyendo en reclamar la cantidad solicitada y haciendo responsable del retraso de la obra al arquitecto director de la misma, afirmando que actuaba, a su vez, como contratista. El arquitecto reclamó contra la liquidación, desestimándose la petición, a la vez que se le autorizaban las nuevas obras a realizar:

Autorizar a Don Manuel Rivera Vera, para ejecutar las nuevas obras que solicita en la fábrica llamada «El Tarajal» desestimando la reclamación que formula contra liquidación y penalidad que se le ha girado por anteriores obras. ${ }^{16}$

Hacia finales de 1931 llegó la autorización para inicio de la actividad productiva: «autorizar a Don Manuel Romero Raggio para instalar una fábrica de azúcar en terrenos del Tarajal, quedando obligado a ejecutar las obras que se señalan en los informes técnicos y al pago de los derechos que con arreglo a tarifa le corresponda» ${ }^{17}$. La fábrica quedó terminada este mismo año, ya que en el fuste de su imponente chimenea figura la inscripción «A.M.E.T. 1931», que correponde al año de su construcción y el nombre de la sociedad promotora (Azucarera Malagueña El Tarajal). La licencia para comenzar a operar se obtuvo del ayuntamiento el 29 de noviembre de 1931 (Heredia y Lorente, 2003: 162).

14 La documentación conservada aún no ha sido analizada y ordenada por los técnicos del archivo, por lo que no existen legajos de ornato disponibles de estos años.

15 (A)rchivo (M)unicipal de (M)álaga, Actas Capitulares vol. 336 fo. 113-113v, sesión 29 de mayo de 1931.

16 A.M.M., Ibidem fo. 181

17 A.M.M., Actas Capitulares vol. 237, fo. 96v, sesión 29 de noviembre de 1931 


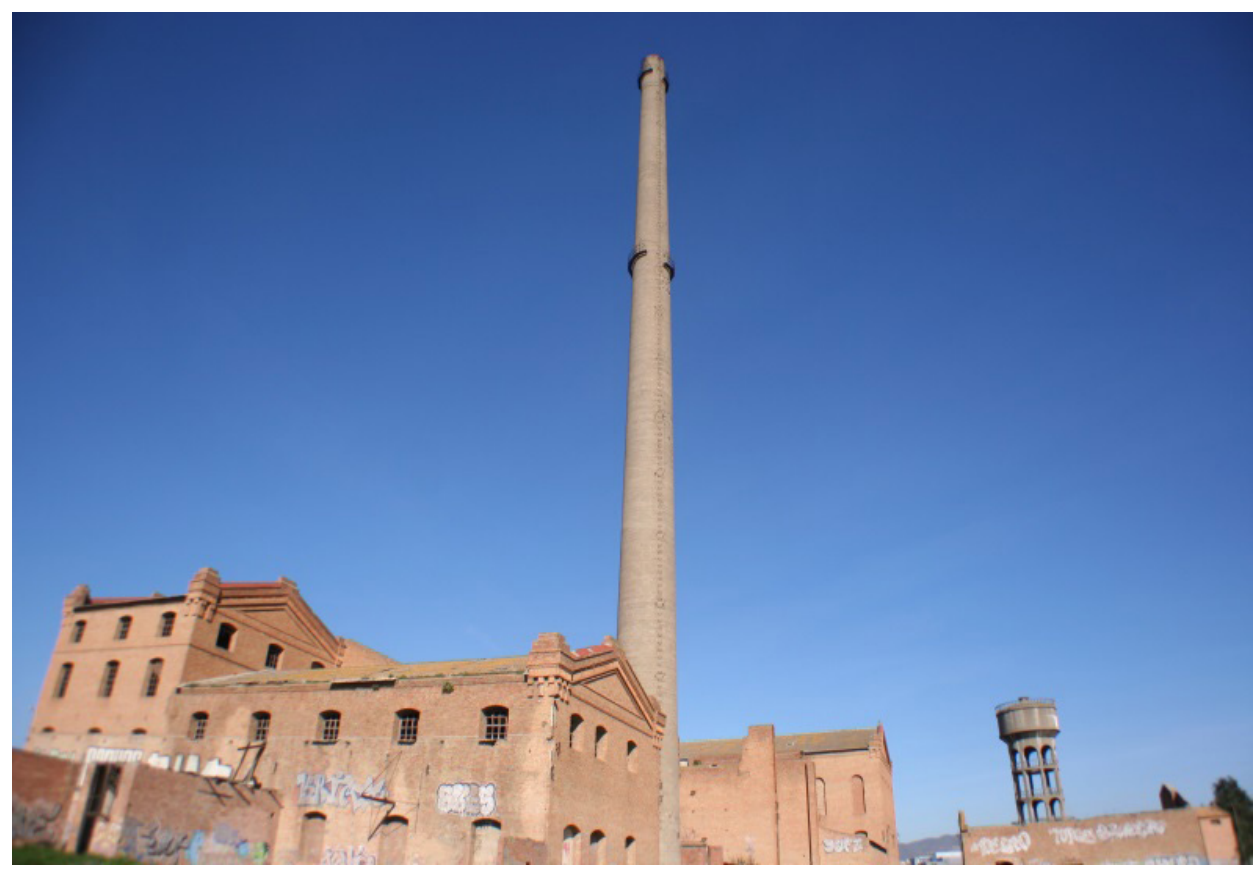

Figura 5. Vista general de la fábrica. Foto: Francisco J. Rodríguez Marín.

Llama la atención que habiendo sido el presidente alcalde y el arquitecto director y autor del proyecto concejal y arquitecto municipal, continuasen litigando respecto al pago de las tasas que correspondían:

Desestimar la reclamación formulada por Don Manuel Romero Raggio, sobre exención del derecho de apertura de establecimiento por cuanto a la fábrica de azúcar denominada «El Tarajal» por tratarse de un establecimiento público y existir un epígrafe en la Tarifa del Arbitrio que dice «Establecimientos e industrias no comprendidas en ningún epígrafe de esta tarifa», abonarán por derechos de apertura el $15 \%$ del valor de venta. ${ }^{18}$

Esta última referencia documental nos sirve para confirmar que en los primeros meses de 1932 la fábrica se hallaba a punto de comenzar su actividad en la que sería su primera zafra, que en España suele iniciarse en abril y prolongarse hasta junio.

\section{UN NOTABLE EJEMPLO DE ARQUITECTURA INDUSTRIAL}

Málaga constituyó un temprano ejemplo de desarrollo industrial, no solo a efectos cronológicos, sino también en términos cuantitativos, ya que hacia mediados del siglo xIX era la segunda ciudad industrial de España tras Barcelona, aunque en algunos sectores concretos -el azucarero entre ellos-, su primacía está 
fuera de duda. Una serie de hechos históricos y estructurales ${ }^{19}$ determinaron un declive, que nunca supuso una desaparición total de la actividad productiva industrial, que experimentó una notable recuperación en la segunda década del siglo xx (RoDRíGUEZ, 2003). No obstante, Málaga entró en un nuevo ciclo económico hacia la década de los años sesenta orientado, primordialmente, hacia el turismo, lo que determinó le pérdida de la inmensa mayoría de su patrimonio industrial.

En el momento de iniciarse el proceso de escrituración de la parcela, 1930, sus límites estaban definidos por la carretera de Cártama al norte; al sur por la línea de Ferrocarriles Andaluces, que ejercía de separación respecto al resto de la finca de la cual fue segregada; al este por un camino de servidumbre que la separa de la finca Santa Teresa o Cantarranas; y por el oeste por un camino que conduce hasta Churriana por el acueducto del Rey. La superficie de la que disponía la parcela destinada a uso industrial ascendía a 15 has., 47 áreas y 70 centiáreas. ${ }^{20}$

La descripción de la finca en el registro correspondiente actualiza su superficie a $3792,68 \mathrm{~m}^{2}$ e incluye los edificios mencionados y demolidos en 2013: un pabellón o almacén que se hallaba en alberca, ${ }^{21}$ seis viviendas para obreros de planta rectangular y una sola planta de altura, portería de una sola planta, el edificio industrial propiamente dicho y rieles de conexión con el apeadero de los Ferrocarriles Andaluces. ${ }^{22}$ Esto último es un detalle particularmente interesante, pues para una fábrica ubicada entonces en mitad del campo y aislada de núcleos de comunicación el ferrocarril cobraba un papel esencial para dar salida a la producción de azúcar con destino a los mercados.

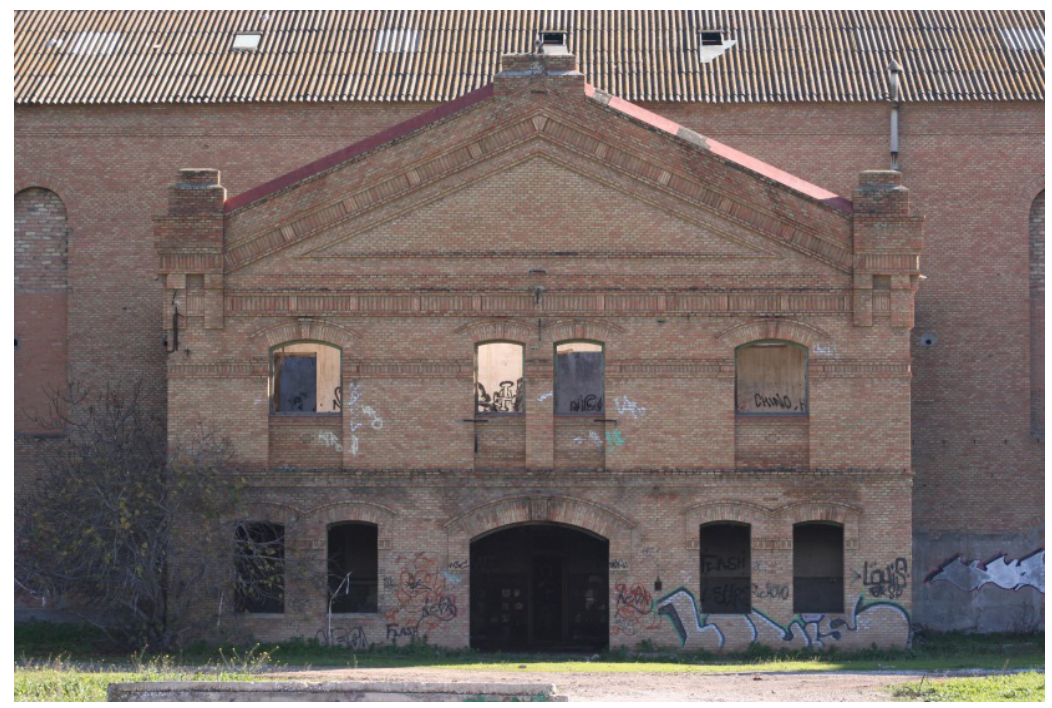

Figura 6. Pabellón de ingreso. Foto: Francisco J. Rodríguez Marín.

19 Carencia de carbón mineral para abastecer a las fábricas siderúrgicas, la crisis de la filoxera y su repercusión en las industrias auxiliares, la competencia de la metalurgia vasca recuperada y modernizada al término de las guerras carlistas, varias heladas concatenadas hacia finales del siglo XIX e inexistencia de ferrocarril, que llegó de forma tardía, son los hechos más relevantes.

20 Escritura de constitución de la sociedad mercantil.

21 Conservaba sus muros perimetrales, aunque carente de techumbre.

22 Nota simple informativa, Registro de la Propiedad n 15 de Málaga. 
En la construcción se invirtieron 1.145 .000 pesetas, que abarcaban el edificio principal o de producción, un pabellón de oficinas, almacenes y talleres, una vivienda para el jefe de estación, viviendas para los trabajadores y el ingeniero director e ingeniero químico, además de portería y casa de báscula (HeREDia y LORENTE, 2003: 279-280). Todas estas construcciones han desaparecido, con la única excepción del edificio principal de la fábrica, que se conserva íntegro.

$\mathrm{Su}$ planta resulta asimilable a una «H» de forma irregular cuyo pabellón de ingreso se destaca adelantándose respecto a la alineación de fachada. La totalidad del edificio está construido con ladrillo visto de tonalidades que oscilan desde el anaranjado intenso al amarillo pálido, alternadas de forma aleatoria. Los muros, que son de carga, presentan un considerable espesor. Esta robustez de la estructura portante, unida a la ligereza de la cubierta, que es de fibrocemento ondulado sobre cerchas metálicas, permite unas extraordinarias luces, con naves de impresionante amplitud sin apoyos intermedios. En su parte interna los muros de las estancias mayores muestran las muescas de haber contado con un forjado intermedio, hoy inexistente, que probablemente no cubriría la totalidad del espacio, sino que recorrería el perímetro interior para sustentar en la planta superior las tachas de concentración de los jugos, tal y como era usual en las fábricas de azúcar o ingenios dotados de tecnología de vapor. ${ }^{23}$

Pese a la modestia de su cubierta, debe destacarse que la Azucarera El Tarajal no se trata de un edificio industrial concebido en clave de exclusiva funcionalidad, sino que, por el contrario, ofrece calidad constructiva, armonía y notables concesiones a la estética que demuestran que sus promotores perseguían beneficiarse del prestigio que suponía dotarse de un inmueble de calidad y aparente. Todos los vanos -dispuestos con regularidad-son de arcos rebajados y cuentan con antepechos en la planta superior y recercados o monteras elaborados en relieve con el mismo ladrillo. Las portadas de los tres cuerpos destacados de la fachada principal cuentan con grandes frontones triangulares delimitados por varios frisos concéntricos elaborados igualmente con ladrillos en diferentes disposiciones. Con este mismo juego estético se han resuelto unos remates dispuestos en los ángulos sustentados por grandes mensulones. Estos elementos decorativos ya estaban presentes en otras obras del arquitecto, como Villa Suecia (1904) o los desaparecidos cines Moderno (1913) y Goya (1923), obras tempranas del mismo arquitecto (LARA, 1988:71 y 95). Villa Suecia aún se conserva, a diferencia de las salas cinematográficas, que han desaparecido y solo pueden documentarse mediante fotografías. En estos ejemplos citados los remates adoptaban perfiles curvos, ya que parten de las tendencias estilísticas modernistas que el arquitecto demostró desde los inicios de su actividad profesional, evolucionando posteriormente hacia una mayor depuración de formas. En la fábrica que nos ocupa han pasado a mostrar un aspecto rígido y cuadrangular con aristas rectas y muy marcadas, fruto, entre otras consideraciones, de la ausencia de revoco para el ladrillo.

23 Así se observa en láminas del catálogo de Fives-Lille (PIÑAR y GiménEZ, 1999) y el repertorio de litografías de Cuba (López, 1999: 163-167), así como en los edificios de ingenios azucareros conservados en Torre del Mar y Frigiliana (Málaga). Para más información sobre los ingenios industriales de la Axarquía puede verse el libro de Francisco CAPILla LuQue (2017). Los ingenios azucareros granadinos respondían al mismo patrón constructivo en su arquitectura (RoDRíGUEZ et al.., 2000: 147, 202) 
La fábrica de azúcar El Tarajal (Málaga), obra del arquitecto Manuel Rivera Vera

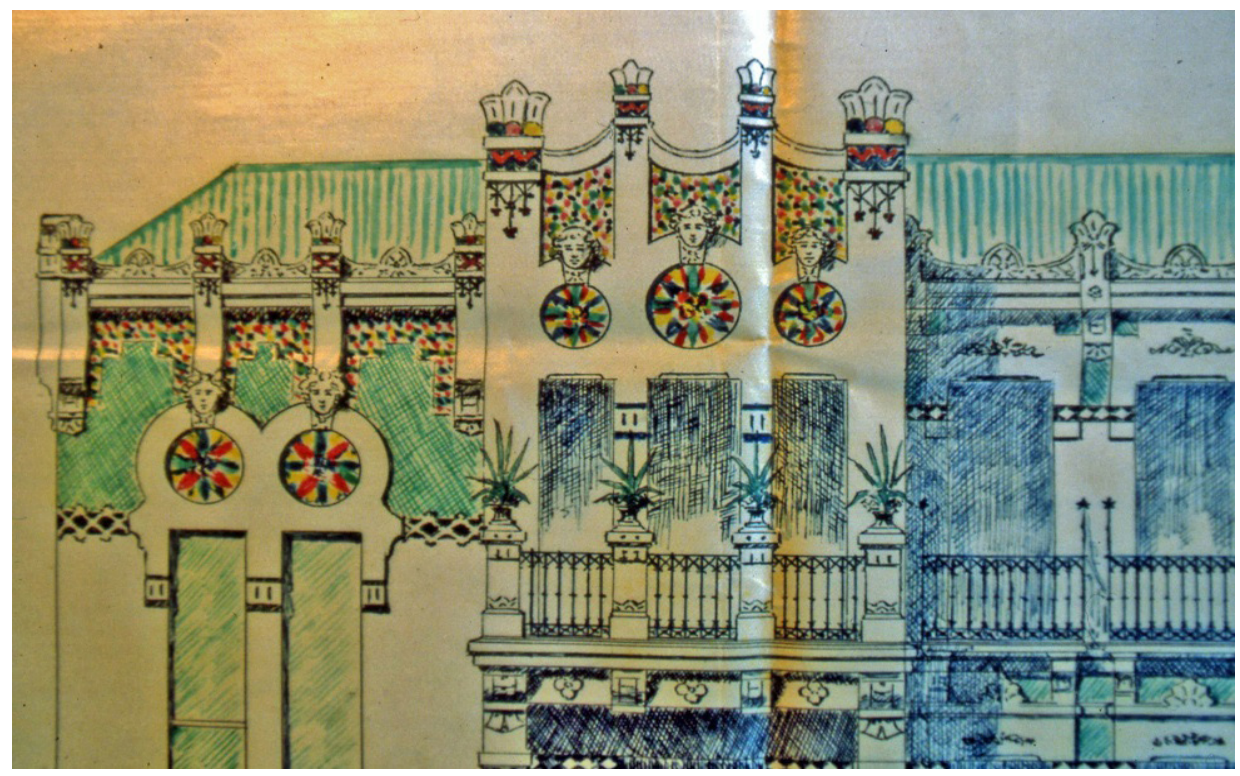

Figura 7. Plano de fachada del proyecto de Villa Suecia (detalle).

Archivo Municipal de Málaga.

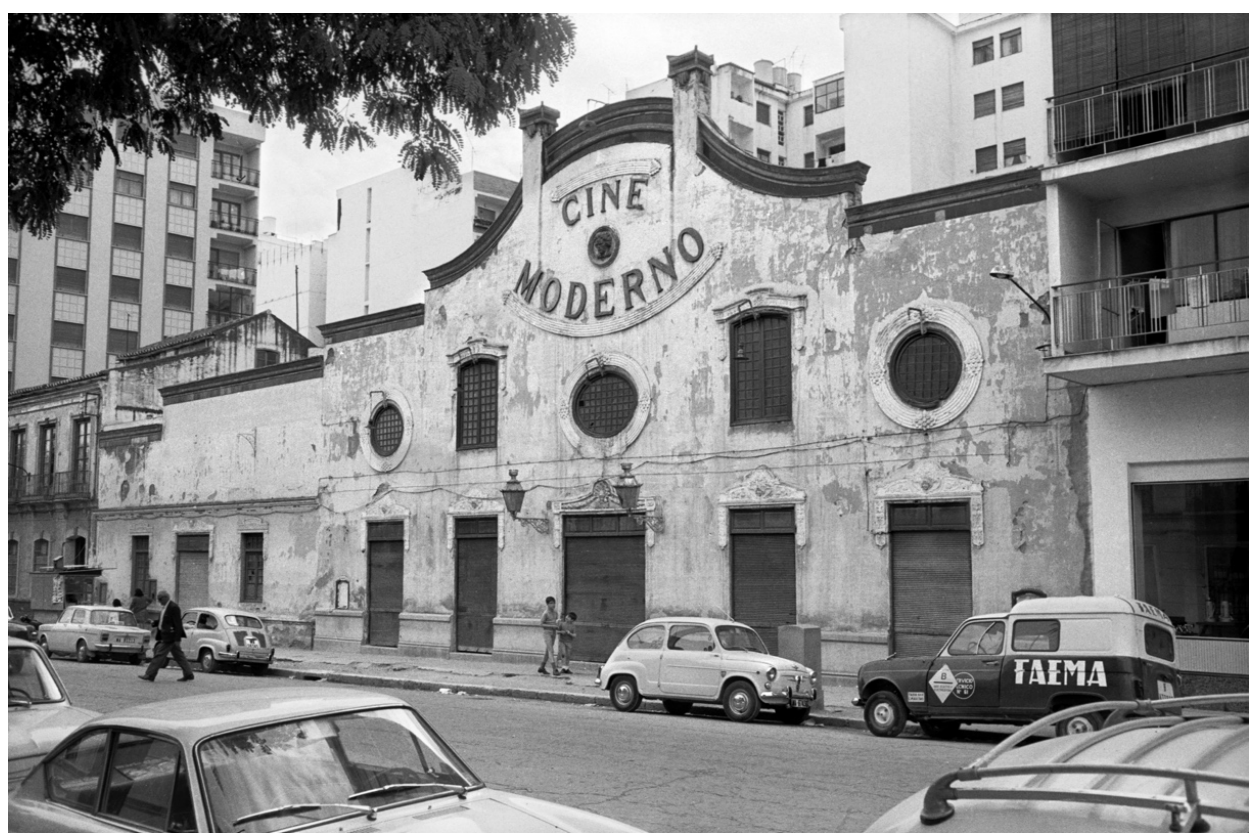

Figura 8. Cine Moderno (desaparecido). Archivo Arenas. 


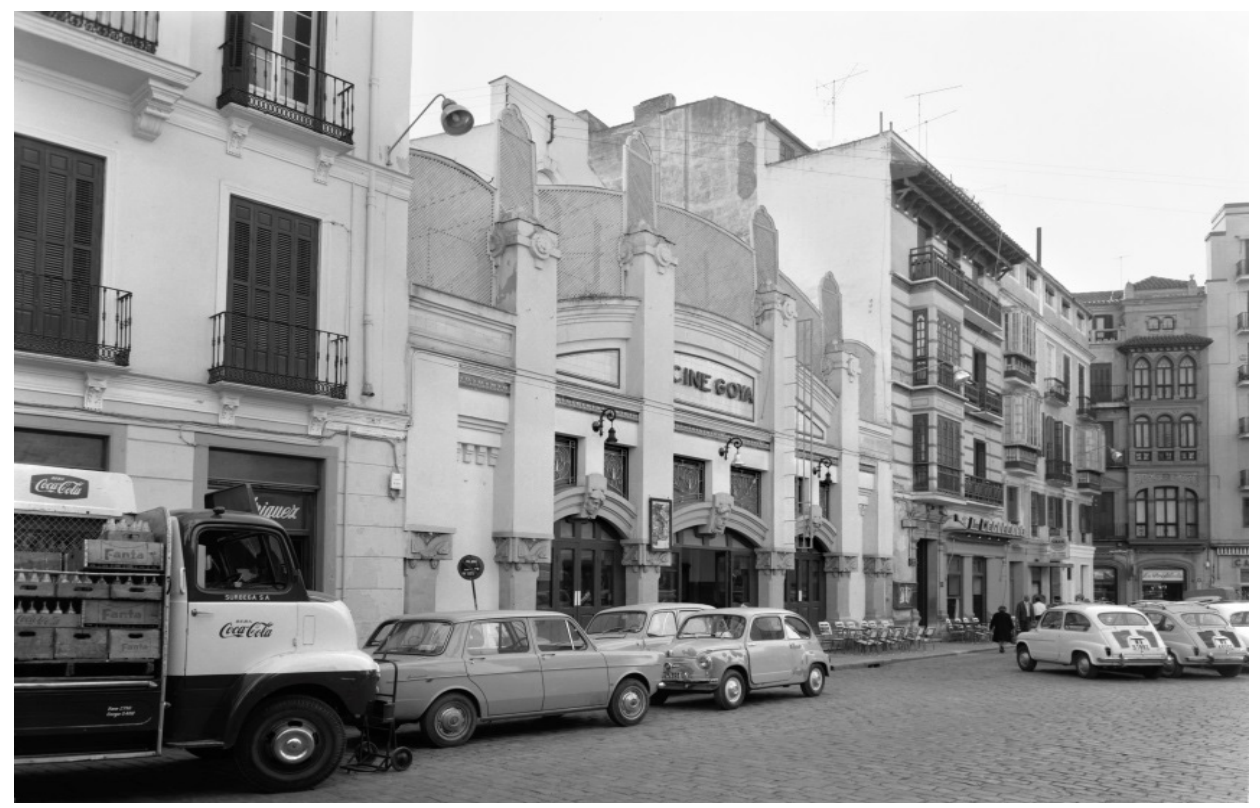

Figura 9. Cine Goya (desaparecido). Archivo Arenas.

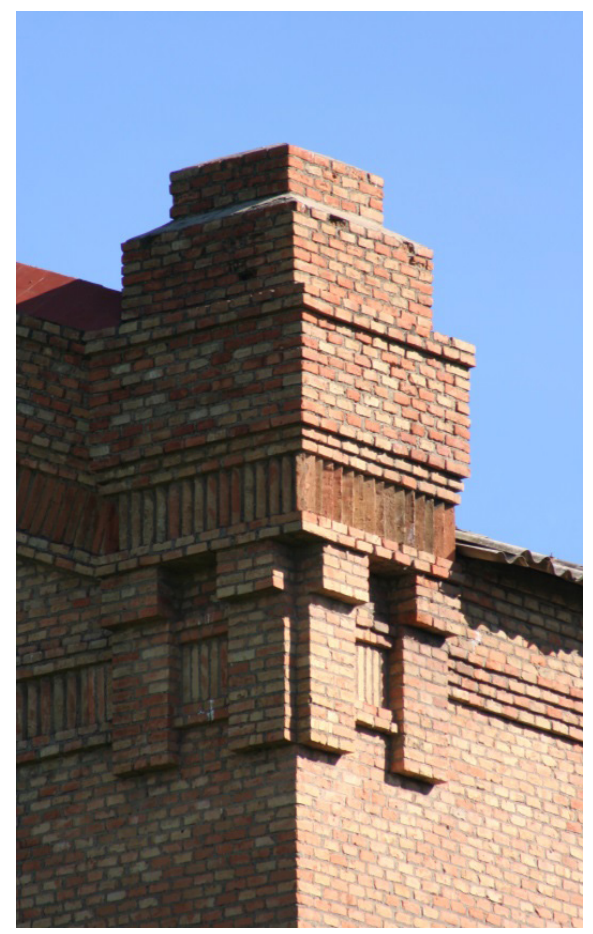

Figura 10. Remate decorativo de la fachada. Foto: Francisco J. Rodríguez Marín. 
El pabellón central acoge en su interior un amplísimo zaguán dotado de un alto zócalo de azulejería con tonos predominantes blanco y azul, representando escenas campestres, aunque los efectos del vandalismo han hecho disminuir los azulejos que aún puedan encontrarse íntegros y sin fragmentar. En una habitación contigua aún puede observarse una gran caja de caudales cuyo peso ha preservado de la rapiña a la que ha sido sometido el resto del edificio.

En la parte posterior del inmueble se reconoce el espacio en el que hasta no hace mucho estuvo la caldera, que ha sido desvalijada por chatarreros. En ella se quemaría el bagazo ${ }^{24}$ para generar calor y vapor de agua, que sería el generador de la fuerza motriz para poner en movimiento el tren de molinos, así como fuente calórica a emplear en el proceso de depuración, evaporación y concentración de los jugos de caña, y por último, del centrifugado del azúcar, que, resumidamente, son los pasos del denominado sistema Derosne, o sistema industrial para la obtención de azúcar. ${ }^{25}$

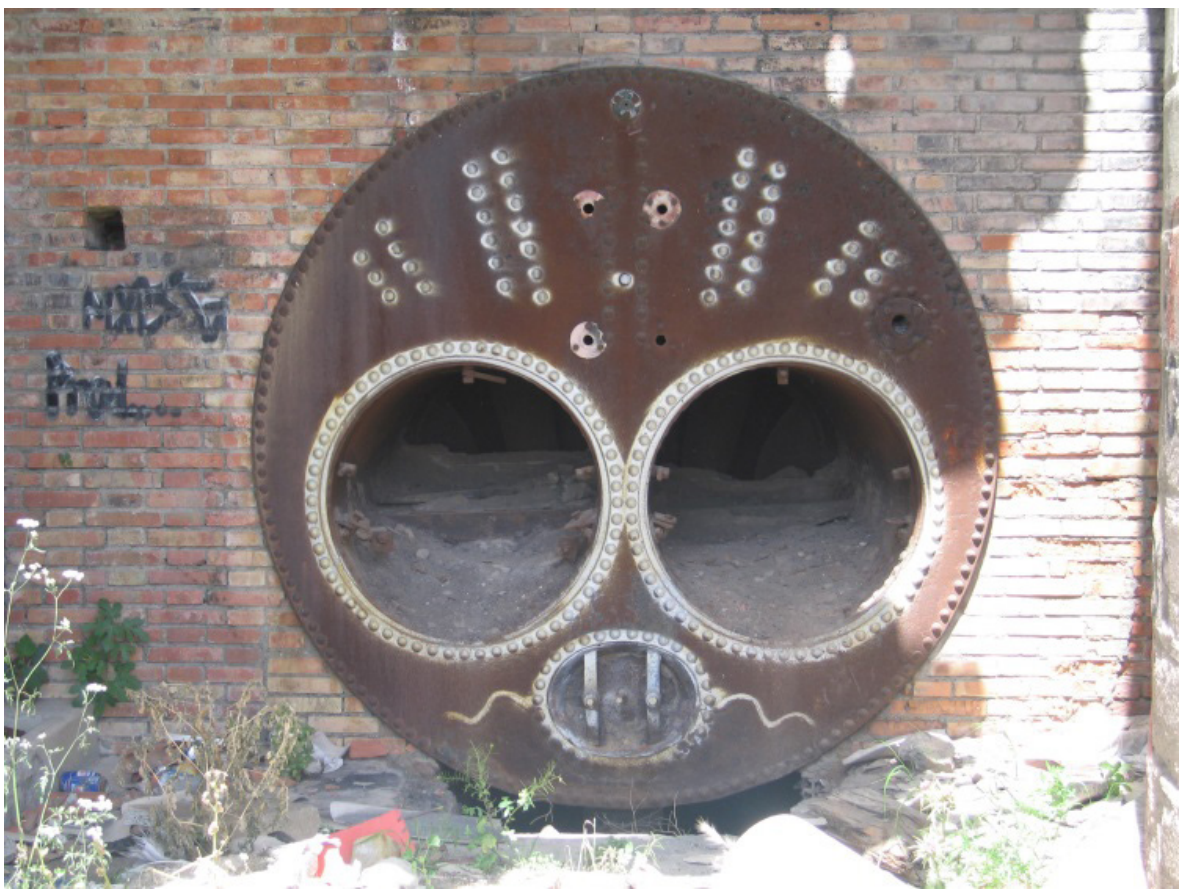

Figura 11. Caldera desaparecida. Foto: Francisco J. Rodríguez Marín.

24 Producto de desecho de la caña una vez prensada integrado por fibra, que una vez secada, podía utilizarse como combustible, entre otros posibles usos.

25 Para mayor detalle del proceso productivo vid. Piñar y Giménez (1998). En el libro de José María FIESTAS (s/f) se recoge un completo registro fotográfico de todas las fases, desde la zafra al envasado, realizado durante la última zafra de la Azucarera de Salobreña, en el año 2006. 
Muy cerca se halla la chimenea, necesaria para la evacuación de los humos generados por la combustión. Presenta una altura considerable $(85,30 \mathrm{~m})$ y el habitual perfil tubular decreciente. Cercano a su base conserva una chapa metálica de porcelana donde puede leerse la inscripción «Erbaut F. Hof Frankfurt a/M.», la cual se interpreta como la procedencia alemana de los materiales constructivos empleados: bloques de hormigón en el exterior y ladrillo refractario en su interior, combinación que comenzó a hacerse habitual en estas fechas. La chimenea dispone de los habituales peldaños metálicos insertos en su fuste y dos anillos en su tramo superior, para facilitar las labores de mantenimiento necesarias en todas las chimeneas industriales.

También debe destacarse la presencia de un depósito de aguas de gran porte, considerable altura y cuidado diseño, construido íntegramente en hormigón armado con estética brutalista. Dispone de dos contenedores cilíndricos de almacenamiento, uno cercano a la base y otro coronando la estructura, pero su diseño a base de grandes arcadas de medio punto y finos pilares cuadrangulares dotan de ligereza a este elemento, que por su singularidad merece conservarse.

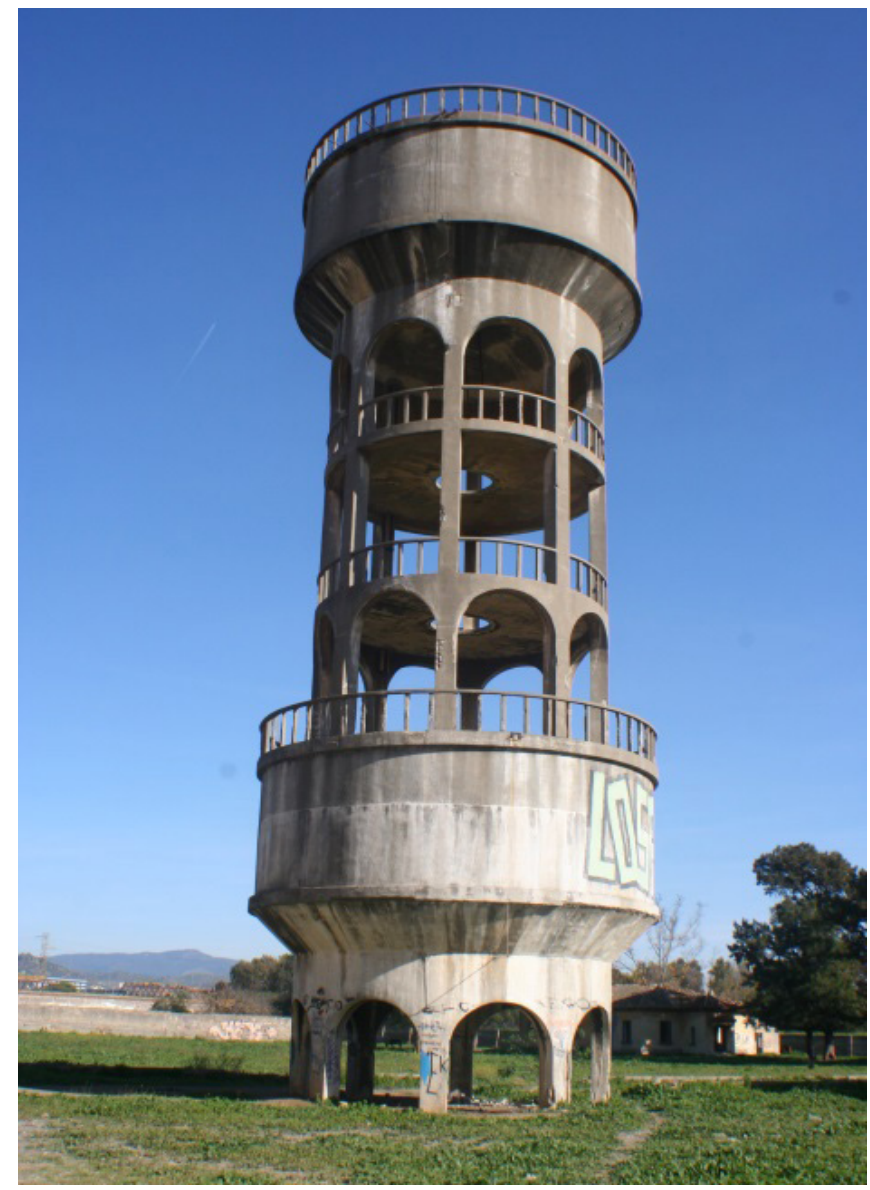

Figura 12. Depósito de aguas. Foto: Francisco J. Rodríguez Marín. 


\section{SITUACIÓN PATRIMONIAL}

La Azucarera El Tarajal surgió en un momento de crisis, entendiendo ésta como de cambio del sector. Surgió con la inteligente decisión de aprovechar tanto la caña de azúcar como su competidora, la remolacha. Otras fábricas de su clase -como Hispania- mantuvieron su actividad hasta la década de los años noventa del pasado siglo. Ésta, sin embargo, apenas si cumplió con la temporalidad del compromiso fijado en sus Estatutos respecto a los agricultores accionistas. Quizás el hecho de que gran parte de su consejo de dirección fuese asesinado al inicio de la guerra civil influyó en el hecho de que el prometedor proyecto empresarial perdiese fuelle. Pero lo cierto es que, desmantelada y fuera de uso en 1939, el inmueble acogió una nueva función como fábrica de tapones de corcho a partir de 1945 (GuZMán, 2019: 107), por lo que muchos malagueños conocen a esta fábrica con el nombre de «la corchera». En su derredor se implantaron otras industrias, como la fábrica de amoniaco de Cros o la textil Intelhorce, y cercano a la azucarera se desarrolló una barriada que adoptó el nombre inicial de la finca: El Tarajal.

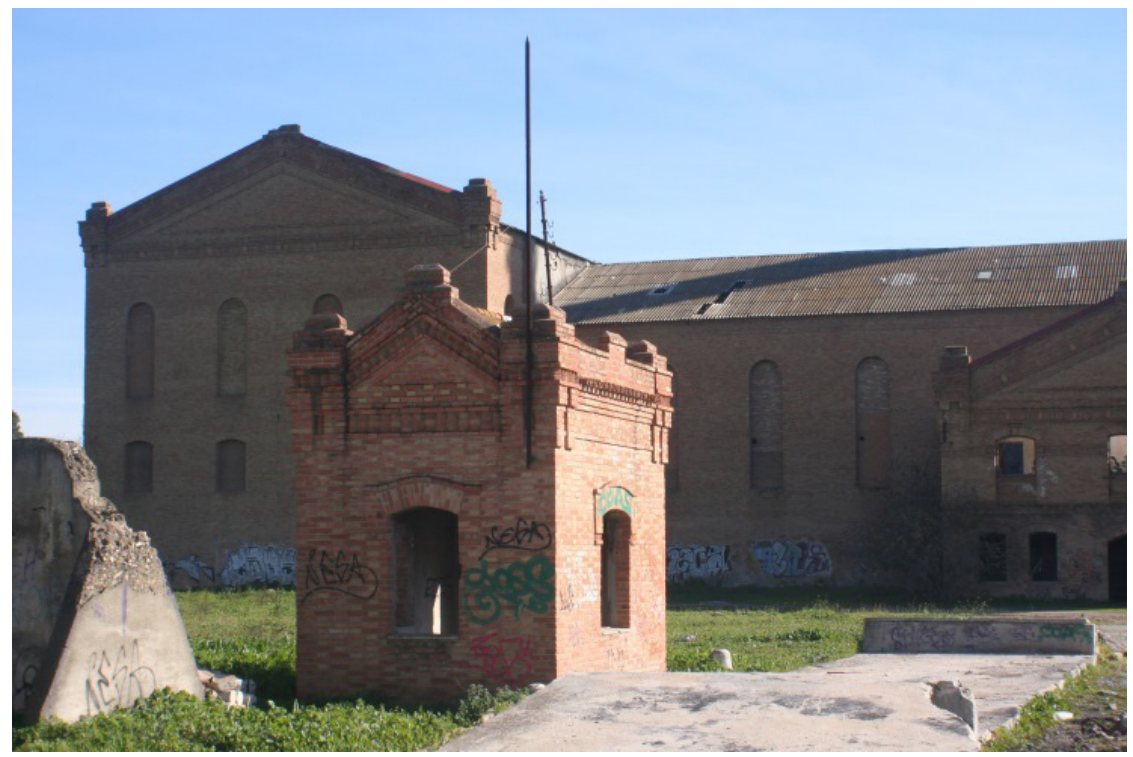

Figura 13. Edificio de báscula (desaparecido). Foto: Francisco J. Rodríguez Marín. 


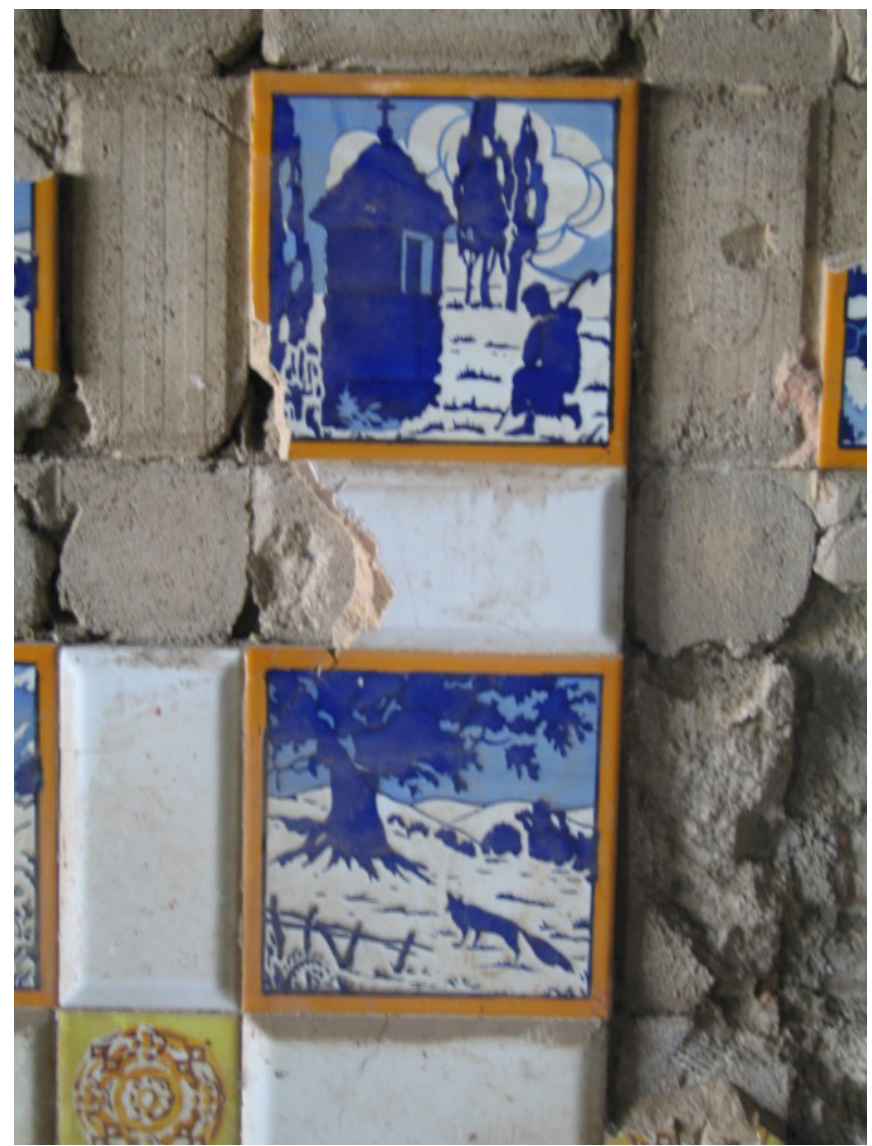

Figura 14. Detalle de azulejos del zaguán. Foto: Francisco J. Rodríguez Marín.

En el término municipal de Málaga es el ejemplo de arquitectura industrial de mayor calidad que se conserva íntegramente. Cuenta con protección arquitectónica de grado II (arquitectónica) en el vigente PGOU de Málaga. Por otra parte, la Consejería de Cultura de la Junta de Andalucía tiene muy avanzada la redacción de un expediente de protección como Lugar de Interés Industrial, con arreglo a la ley del Patrimonio Histórico de Andalucía, lo que implicaría un mayor grado de protección y una más firme garantía de conservación de sus valores patrimoniales. Sobre parte de la parcela, actualmente no edificada, se plantea un proyecto de 361 viviendas libres de bajo más cinco plantas de altura y otras 164 viviendas protegidas de idéntica altura, además de otros usos empresariales. Sería necesario que las actuaciones que se acometan en este espacio se hagan con la sensibilidad necesaria para no perjudicar al que sin duda es el ejemplo más relevante de arquitectura industrial en Málaga, pues las alturas propuestas y la cercanía a la fábrica supondrán su descontextualización. Previamente se demolieron las viviendas del guarda, de obreros y la caseta de la báscula, que 
-no afectados por la exigua protección del PGOU- constituían, sin embargo, elementos que ayudaban a interpretar el funcionamiento de la fábrica.

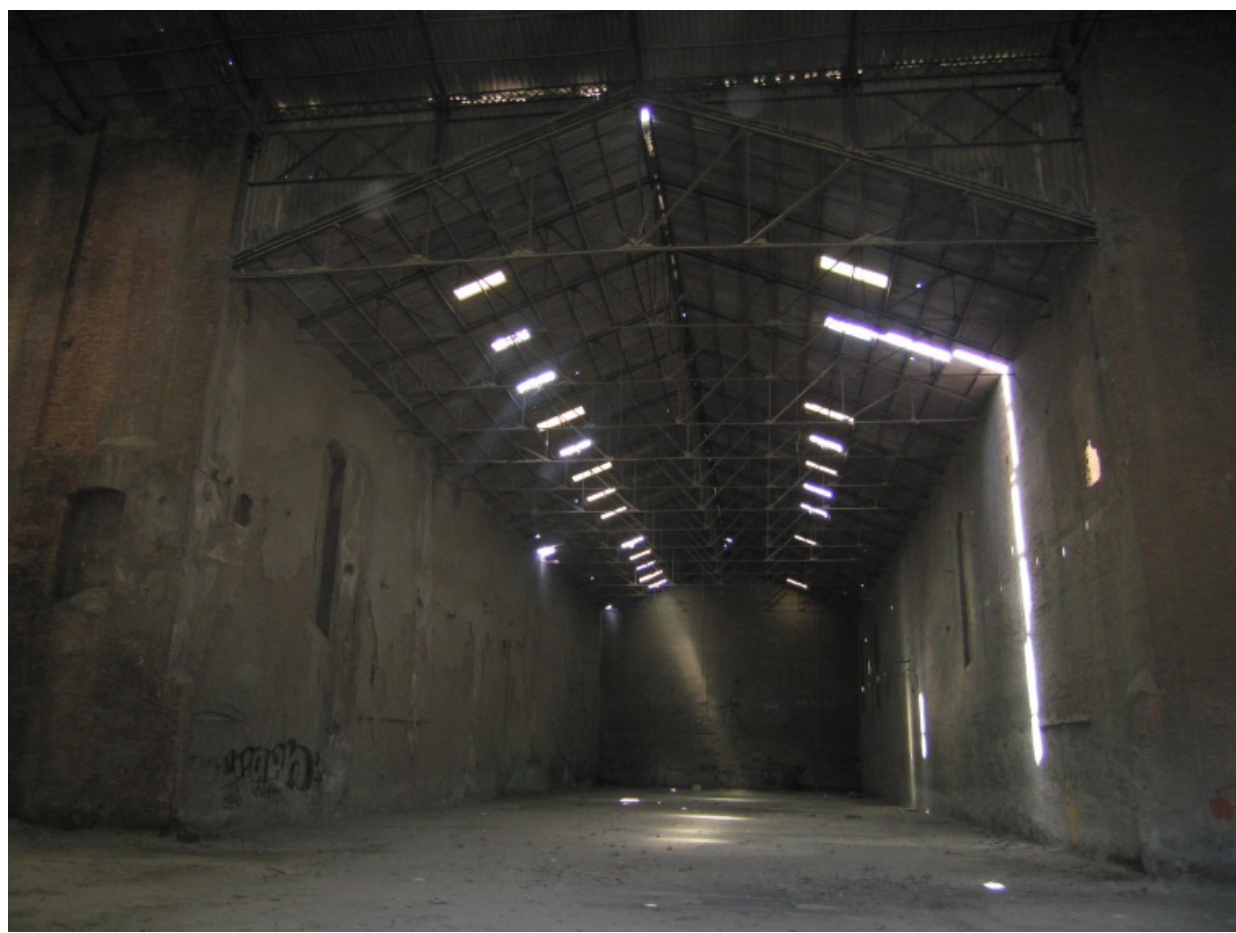

Figura 15. Interior de una de las naves. Foto: Francisco J. Rodríguez Marín.

Sin embargo, el edificio conservado ofrece inmejorables condiciones para su reutilización. Su emplazamiento se hallaba en una posición perimetral y de extrarradio, rodeado de terrenos agrícolas. Pero esta situación ha cambiado. La ampliación del campus de la universidad se encuentra en relativa cercanía y también han mejorado las comunicaciones. Por su calidad arquitectónica y dimensiones es uno de los espacios largamente reclamado por asociaciones patrimonialistas como posible contenedor de un museo de la industria y la tecnología, del que una ciudad con esplendoroso pasado industrial como Málaga, aún carece. Una propuesta de adaptación de este edificio a museo de la industria fue realizada por el investigador Carlos SARRIÁ (2014). Pero lo cierto es que su condición confirma la versatilidad habitual de la arquitectura industrial para adaptarse a diferentes usos. Lo único que no parece admisible es prolongar por más tiempo una situación de abandono que únicamente acelera el deterioro del edificio emblema del patrimonio industrial malagueño. 


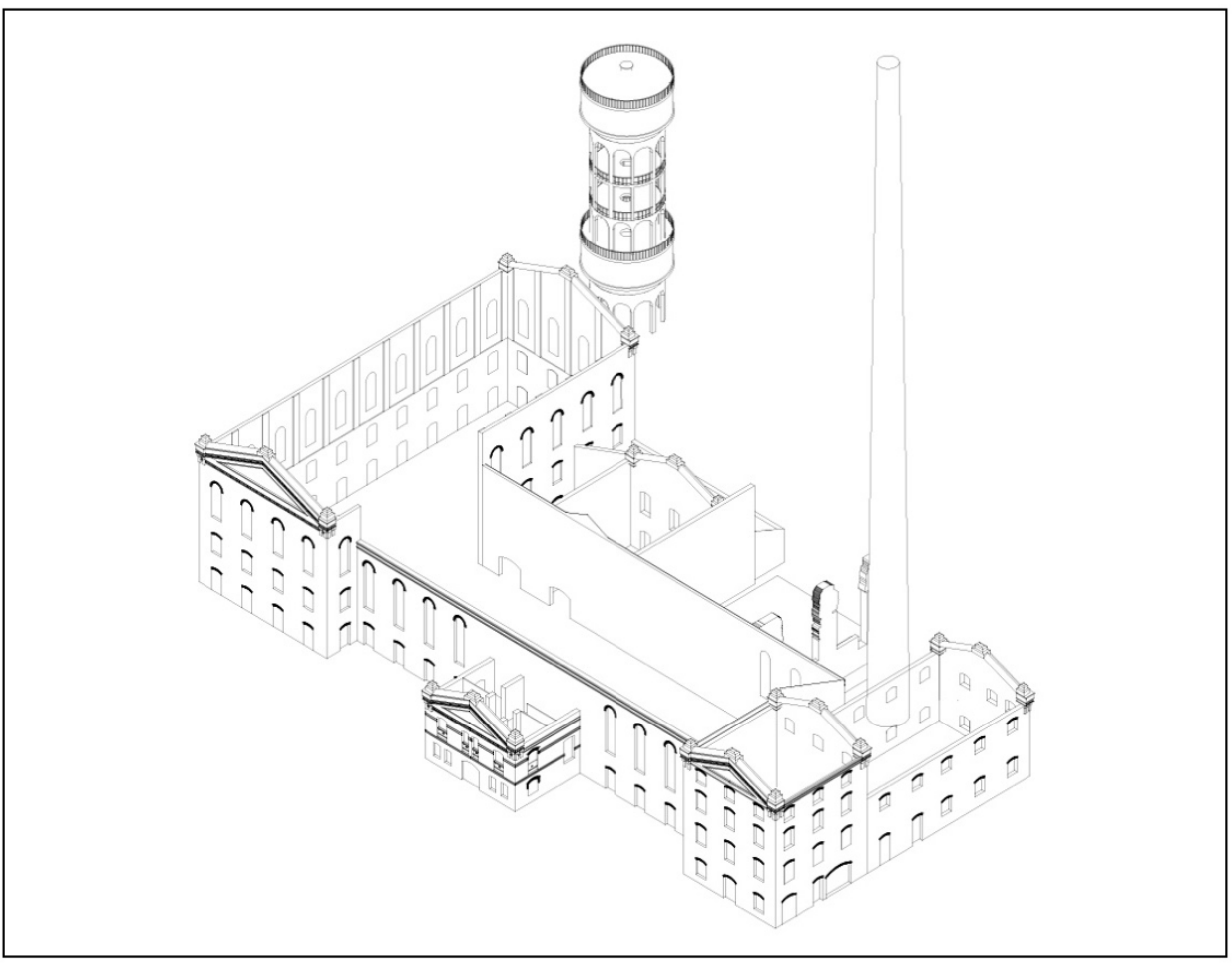

Figura 16. Perspectiva. Autoría: Rodrigo Luque de Diego.

\section{CONCLUSIONES}

La fábrica de azúcar El Tarajal es un claro ejemplo, y el único conservado en la ciudad, de ingenio azucarero accionado por vapor. Estaba tecnológicamente preparado para la transformación, tanto de caña de azúcar como de remolacha, fruto de los intentos del sector por adaptarse a los cambios motivados por el predominio de la remolacha. La breve historia de esta fábrica es un episodio más del intenso desarrollo industrial que experimentó Málaga y las intenciones de la oligarquía local por obtener beneficios de un sector que anteriormente había enriquecido a otras personas y familias. Una recesión económica y la guerra civil acabaron con este proyecto apenas una década después de comenzar.

Afortunadamente ha permanecido el edificio fabril, aunque desprovisto de sus instalaciones auxiliares y complementarias. La autoría del arquitecto Manuel Rivera Vera aquí establecida explica la calidad del inmueble a la vez que revela la intrincada red de conocimientos y contactos entre los promotores de esta empresa industrial. 
La fábrica de azúcar El Tarajal (Málaga), obra del arquitecto Manuel Rivera Vera

\section{REFERENCIAS}

Alfaro Gutiérrez, P. (1921): Crónica del viaje de S.M. el Rey D. Alfonso XII a Málaga los días 21 y 22 de mayo de 1921, Imprenta Ibérica

Brotons Pazos, J. (1999): El Embalse del Chorro, un hito en la política hidráulica en el umbral del siglo XX, Confederación Hidrográfica del Sur, Málaga.

Camarero, C.; Campos, J. (dirs.) (1993): Obras hidráulicas en la América Colonial, CEHOPU, Madrid.

CAMBRÓN INFANTE, A. (1999): «La industria azucarera andaluza: la amarga experiencia de Ramón de la Sagra», en De la Sagra, Ramón (1845), Informe sobre el cultivo de la caña y la fabricación de azúcar en las costas de Andalucía, edición facsímil, Asukaría Mediterránea, Granada.

Estatutos de la Sociedad Anónima «Azucarera Malagueña El Tarajal» (1930), Tipografía La Moderna, Málaga.

Fiestas, J. Mà. (s/f): La caña de azúcar. La última azucarera de Europa. Salobreña. Granada, Fuente Aporta Ediciones.

García Montoro, C.; Parejo Barranco, J.A. (1986): Historia de la Cámara Oficial de Comercio, Industria y Navegación de Málaga (1886-1986), COCINM, Málaga.

GuZmán VAldivia, A. (2019): «La industria del azúcar en la provincia de Málaga», en A. Guzmán y A. Santiago (coord.) (2019), Málaga. Pasado y presente de una ciudad industrial, Málaga Tech Park y APIDMA, Málaga: 89-110.

Heredia García, G.; Lorente Fernández, V. (2003): Las fábricas y la ciudad (Málaga, 1834-1930), Arguval, Málaga.

Lara García, Mª.P. (1988): Historia de los cines malagueños (desde sus orígenes hasta 1946), Diputación Provincial de Málaga

López LueNGO, J. (2004): «Arsenio Rueda Marín. Regenerador de la caña azucarera» I, II y III, El Faro no $.3829,3830$ y 3831, Motril.

López NúÑEz, O. (1999): «Imágenes de Cuba colonial», en Grabados Coloniales Cubanos, catálogo de exposición, Diputación Provincial de Málaga, Málaga: 6-17.

Luque De Diego, R. (2016): La Corchera. Cooperativa de trabajadores en la fábrica del Tarajal, Proyecto Fin de Carrera, Escuela Superior de Arquitectura de Málaga.

Navascués Palacio, P. (1973): Arquitectura y arquitectos madrileños del siglo XIX, CSIC, Madrid.

Navascués Palacio, P.; Quesada Martín, Mª J. (1992): El siglo xix. Bajo el signo del Romanticismo, Sílex, Madrid.

Pérez Ortiz, Mª.J. (2017): «Hinojosa: un poeta del 27 en el umbral del olvido», La Opinión de Málaga, 4 de noviembre de 2017.

Pezzi Cristóbal, P. (eds.) (2019): El azúcar en la provincia de Málaga, Sociedad de Amigos de la Cultura de Vélez-Málaga, Málaga.

Piñar SAmos, J. y Giménez Yanguas, M. (1998), «Las fábricas azucareras de la costa granadina», en VV.AA., El patrimonio tecnológico de Andalucía, Consejería de Educación y Ciencia, Junta de Andalucía, Sevilla: 167-204.

Piñar SAmos, J.; Giménez Yanguas, M. (1999), «Introducción» a edición facsímil de Compagnie de Fives-Lille pour Construction Mécaniques et Enterprises. Matériel de Sucrerie (1880), Asukaría Mediterranea, Granada: 11-41.

Rodríguez López, J. et al. (2000): Granada. Memoria de un cambio de siglo, Fundación Caja de Granada, Granada. 
Rodríguez Marín, F.J. (1992-1993): «Manuel Rivera Vera (1879-1940). Último eslabón de dos generaciones de arquitectos (II)», Boletín de Arte, 13: 235-255.

Rodríguez MARíN, F.J. (2003): «Málaga 1850-1920. La arquitectura industrial como exponente de una actividad económica», III Congreso de Historia de Andalucía, Universidad de Córdoba: 233-254.

Rodríguez Marín, F.J. (2009): «Memoria de un pasado reciente: las fábricas de azúcar de Málaga (España)», II Encuentro Internacional Patrimonio Industrial Agroalimentario, TICCHI, Córdoba (Argentina), Editora Literaria, Córdoba.

RodríGuez MARÍN, F.J. (2012): «La experimentación agrícola como apoyo de la actividad industrial: las estaciones de agricultura de Motril, Torrox y Churriana», I Jornadas Andaluzas del Patrimonio Industrial y la Obra Pública, Fundación Patrimonio Industrial de Andalucía, Sevilla.

Santiago Ramos, A.; Bonilla Estébanez, Isabel y Guzmán Valdivia, A. (2001), Cien años de historia de las fábricas malagueñas (1830-1930), Acento Andaluz, Málaga.

Santiago Ramos, A.; Bonilla Estébantz, I.; Guzmán Valdivia, A. (2005): «La caña de azúcar, un referente cultural en la Axarquía», Ballix, 2: 67-88.

SARrí́ FERnÁndeZ, C. (2014): «Propuesta para la creación y ubicación del museo de la industria de Málaga», Isla de Arriarán, 37: 7-44. 
